\title{
THE EFFECTS OF L-CARNITINE IN BUDD-CHIARI SYNDROME IN A DOMESTIC CAT
}

\author{
Aliye Sağkan Öztürk ${ }^{1}$, Nuri Altuğㄹ, Serkan İrfan Köse ${ }^{1}$, Oktay Hasan Öztürk \\ ${ }^{1}$ Department of Internal Medicine, Faculty of Veterinary Medicine, \\ Mustafa Kemal University, 31040, Hatay, Turkey \\ ${ }^{2}$ Department of Internal Medicine, Faculty of Veterinary Medicine, \\ Namık Kemal University, 59030, Tekirdă̆, Turkey \\ ${ }^{3}$ Department of Biochemistry, Faculty of Medicine, Akdeniz University, \\ 07985, Antalya, Turkey
}

Received 30 July 2015; Received in revised form 12 November 2015; Accepted 17 November 2015

\begin{abstract}
This paper describes a thrombosis in the vena cava caudalis of a 15 year-old cat with ascites. Trauma and eventually feline enteric corona virus infection in the cat were not detected. In the intrahepatic region, a blockage of vena cava caudalis was brought to light by ultrasonographic imaging. An aspirate of abdominal fluid revealed modified transudate. Liver enzyme levels were increased in the serum sample of the cat. The levels of total oxidant status (TOS) and total antioxidant status (TAS) were elevated in the peritoneal fluid. Liver protection diet with L-carnitine, diuretic therapy and antimicrobial drugs were administrated for treatment of the cat. During the continuous treatment, the amount of abdominal fluid decreased, but never completely absorbed. L-carnitine was administered to the cat during the time of treatment, and subsequently the levels of liver enzymes decreased. However, the cat died because of recurrent ascites and persistent thrombosis. In conclusion, ultrasonographic examination was very reliable, non-invasive and highly useful diagnostic method for BCS and L-carnitine has crucial effects on the quality of life, energy metabolism and liver enzyme levels. However, the blockage of the vena cava caudalis could not completely respond to medical treatment and thrombosis should be eliminated by surgical intervention.
\end{abstract}

Key words: Budd-Chiari syndrome, cat, L-carnitine, peritoneal fluid

\section{INTRODUCTION}

Budd-Chiari syndrome (BCS) is a clinical condition resulting from the blockage of the main hepatic veins or vena cava caudalis $(1,2)$. Nakamura et al. (3) determined membranous obstructions affected both vena cava caudalis and the hepatic veins. In $18 \%$ of cases, only the vena cava caudalis was affected, while the hepatic veins were affected in $10 \%$ of the cases. The blockages in

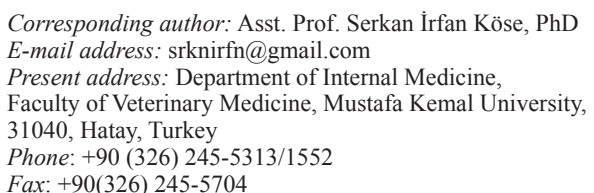

Copyright: (C) 2015 Ozturk A.S. This is an open-access article published under the terms of the Creative Commons Attribution License which permits unrestricted use, distribution, and reproduction in any medium, provided the original author and source are credited.

Competing Interests: The authors have declared that no competing interests exist.

Available Online First: 25 November 2015

Published on: 15 March 2016

http://dx.doi.org/10.1515/macvetrev-2015-0066 the vena cava caudalis can be severe and may cause hepatocellular necrosis, hepatic failure, cirrhosis, and encephalopathy $(4,5)$. BCS is very rare in the literature and practice in domestic animals. Therefore, the aim of this case report was to describe Budd-Chiari syndrome in a cat, with mild clinical, ultrasonographic and laboratory findings, as well as treatment of affected cat. Laboratory findings were used to evaluate the effects of L-carnitine on liver and oxidative status of the cat.

\section{CASE REPORT}

A 15 year-old female cat, with clinical sings of vomiting and severe abdominal distension was admitted at the clinic (Fig. 1).

There was no history data of any trauma and infection with feline enteric coronavirus (FCoV). Polymerase Chain Reaction (conventional-PCR) on corona virus was negative. The clinical and the 


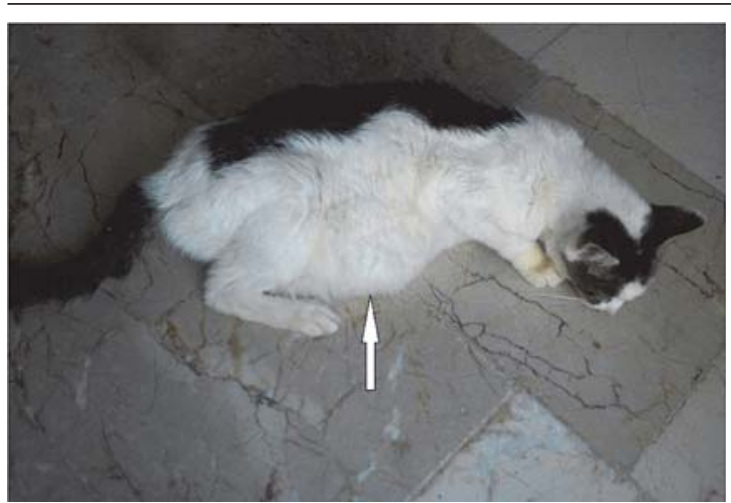

Figure 1. A 15 year-old female cat with abdominal distension (white arrow)

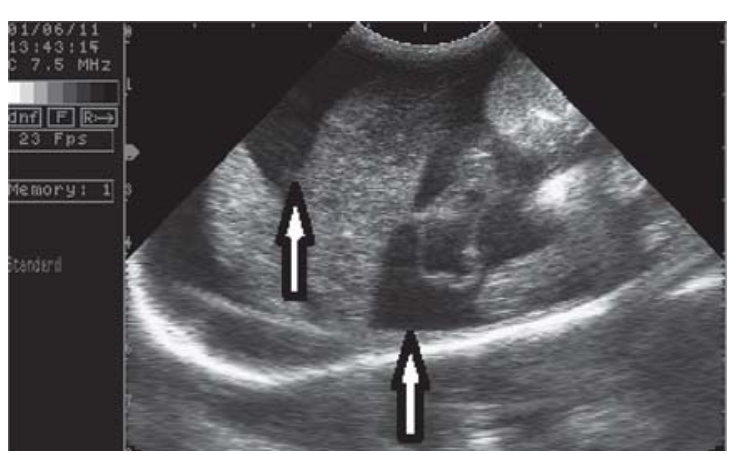

Figure 2. The ascites is seen in the anechoic area

ultrasonographic examination revealed abdominal pain, hepatomegaly, ascites, and increased liver echogenicity (Fig. 2).

After the aspiration of abdominal fluid, a cytology smear was prepared and the fluid was described as modified transudate. Cytology findings in the cell population of the aspirated abdominal fluid described mesothelial cells, macrophages, nondegenerate neutrophils and small lymphocytes. A blockage of the vena cava caudalis at the intrahepatic region called Budd-Chiari syndrome was found with ultrasonographic examination. The location

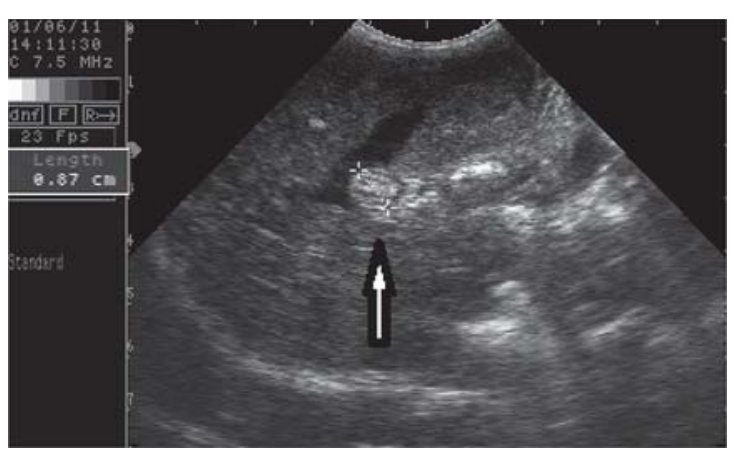

Figure 3. Enlarged vena cava caudalis from thrombosis (ventradorsal position-transversal cross-section) of the thrombus was confirmed by longitudinal and transversal cross-section. The thrombus was $0.87 \mathrm{~cm}$ in diameter at the junction of the hepatic vein and the vena cava caudalis (Fig. 3 and Fig. 4).

During this study, we proposed a hepatoprotective and lower salt diet (easy digestible foods with high quality protein and highly digestible protein; Prescription Diet $\AA \mathrm{h} / \mathrm{d} \AA, \quad \mathrm{d} / \mathrm{d} \AA$ feline-Hill's Pet Nutriton). The following medical therapy was recommended: cefuroxime axetyl $25 \mathrm{mg} / \mathrm{kg} /$ body weight 10 days, furosemide $2 \mathrm{mg} / \mathrm{kg}$ body weight 10 days, and total $330 \mathrm{mg}$ dosage L-carnitine. After fortnight of therapy, the cat's appetite was increased and laboratory results got better as well. Obtained biochemical results are presented in Table 1. The amount of abdominal fluid in the cat was reduced as a result of the diuretic therapy; but the serum concentration of urea was elevated. A small amount of fluid was detected in the abdomen at the beginning of the therapy. After antibiotics and furosemide treatment, the L-carnitine administration was continued. In the following period, the amount of abdominal fluid increased again and unfortunately the cat died three months after the onset of the disease. The animal owner did not allow the necropsy.

A total of $5 \mathrm{ml}$ blood samples were collected with venipuncture of vena cephalica antebrachi externa. Some biochemical (serum tubes with clot factor) and hematological (tubes for whole blood with EDTA) analyses were performed, such as liver transaminases alanine aminotransferase (ALT) and aspartate aminotransferase (AST), further gamma glutamyl transferase (GGT), total bilirubin, albumin, total protein, direct bilirubin levels, total antioxidant capacity status (TAS) and total oxidant status (TOS), in the serum samples. Furthermore, TAS and TOS in ascites fluid were examined.

Total antioxidant and oxidant capacities were determined colorimetrically (PowerWave XS, BioTek Instrument, Bedfordshire/UK) using a

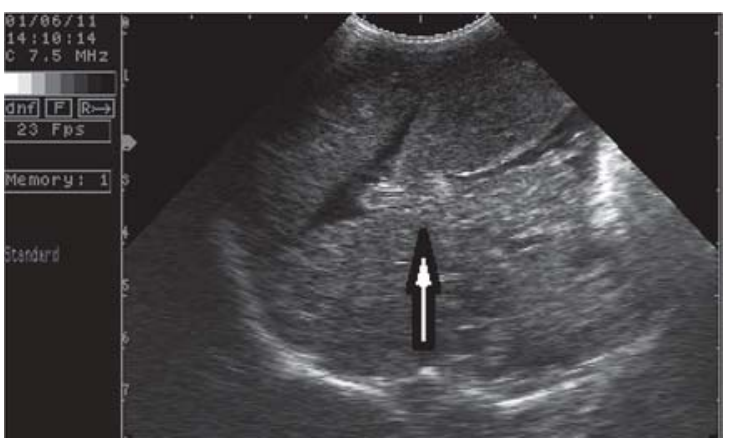

Figure 4. Thrombosis of vena cava caudalis (ventradorsal position-longutidinal cross-section) 
The effects of L-carnitine in Budd-Chiari syndrome in a domestic cat

commercial kit (Rel Assay Diagnostic, Gaziantep, Turkey) as previously described by Durgut et al. (6). Serum TAC was determined using a novel automated measurement method developed elsewhere (7). The results are expressed as $\mu \mathrm{mol}$ of Trolox equivalent/liter. Total oxidant status levels were measured using commercially available kits (Rel Assay Diagnostic, Gaziantep, Turkey). The assay was calibrated with hydrogen peroxide $\left(\mathrm{H}_{2} \mathrm{O}_{2}\right)$, and the results were expressed in terms of micromolar $\mathrm{H}_{2} \mathrm{O}_{2}$ equivalent per liter $\left(\mu \mathrm{mol} \mathrm{H}_{2} \mathrm{O}_{2}\right.$ equivalent/L) (8).

The levels of ALT and AST, total bilirubin and direct bilirubin in the serum sample were marked increased, with regards to the serum albumin and total protein concentration. Serum levels of urea and creatinine were in physiological range at the beginning of the therapy. There were no marked changes in the hematological parameters (Table 1). of hepatic vein stenosis, causing ascites and mild anemia in a cat was described by Schrope (9).

Humans with BCS, have a thin fibrous band or segmental fibro muscular membrane, formed in both supra hepatic areas (entrance of the hepatic veins and from the right atrium), as well as intrahepatically (in the liver) and in the vena cava inferior $(1,3,10)$. A membranous obstruction of the inferior vena cava known as idiopathic Budd-Chiari syndrome in humans is a rare clinical condition (11, 12). In this study, we determined full obstruction in both vena cava caudalis and hepatic vein in the intrahepatic region (Fig. 2 and Fig. 3), called the Budd-Chiari syndrome, by ultrasonographic examination similarly as other studies $(3,9)$.

Liver damage may be increased by oxidative stress. Oxidative stress has an important role in the pathogenesis of viral hepatitis, sepsis and bacterial infections $(13,14)$. Liver enzymes (ALT, AST,

Table 1. Hematological findings in blood samples

\begin{tabular}{lllll}
\hline & \multicolumn{3}{c}{ Blood samples } \\
\cline { 2 - 5 } Parameters & First week & Second week & Third week & Fourth week \\
\hline RBC (x10 $\left.\mathbf{1 2}^{\mathbf{g}} / \mathbf{L}\right)$ & 7.41 & 6.60 & 6.82 & 6.16 \\
HGB (g/L) & 96.0 & 81.0 & 89.0 & 75.0 \\
HCT (\%) & 24.59 & 22.30 & 22.70 & 21.03 \\
MCV (fL) & 33 & 34 & 33 & 34 \\
MCHC (g/L) & 389.0 & 364.0 & 393.0 & 356.0 \\
Total Bilirubin $(\boldsymbol{\mu m o l} / \mathbf{L})$ & 15.39 & 42.75 & 17.1 & $*$ \\
Direct Bilirubin( $\boldsymbol{\mu m o l} / \mathbf{L})$ & 15.39 & 34.2 & 13.68 & $*$ \\
Urea (mmol/L) & 10.353 & 24.99 & 16.422 & 13.209 \\
Creatinine $(\boldsymbol{\mu m o l} / \mathbf{L})$ & 96.356 & 109.616 & 101.66 & 61.88 \\
\hline
\end{tabular}

*Not detected

Concentrations of TAS and TOS were higher in the peritoneal fluid compared with the serum samples (Table 2 and Table 3). Concentration of enzymes was increased, particularly gamma glutamyl transferase (GGT).

\section{DISCUSSION}

This clinical case describes the ultrasonographic and laboratory examinations of BCS. The first case
GGT), oxidative stress index-OSI and TOS increases are marked in animals with fascielosis, while TAS decreases in serum and plasma samples (15). In this study, the levels of TAS and TOS were increased in the peritoneal fluid compared with serum samples (Table 3) and some data supported our findings (14, 16). On the other hand, the level of enzymes was increased at the beginning of treatment, particularly parenchymal enzymes, reported by Braun (17).

The response to medical therapy in the case of $\mathrm{BCS}$ is generally poor. The effect of diuretic therapy

Table 2. Biochemical findings in blood samples and peritoneal fluid

\begin{tabular}{llllll}
\hline \multirow{2}{*}{ Parameters } & \multicolumn{2}{c}{ Blood samples } & \multicolumn{2}{c}{ Peritoneal fluid } \\
\cline { 2 - 5 } AST (U/L) & First week & Second week & Third week & Fourth week \\
ALT (U/L) & 654 & 409 & 273 & 139 & 143 \\
GGT (U/L) & 1534 & 674 & 666 & 33 & 22 \\
Total Protein (g/l) & 54 & $>4$ & $>4$ & 66.0 & $<4$ \\
Albumin (g/l) & 59.0 & 67.0 & $*$ & 21.0 & 17.0 \\
\hline
\end{tabular}


is uncertain (18). We used L-carnitine as liverprotection, a low salt diet and diuretic treatment. Prescribed therapy improved the condition and the quality of life of the cat, but for a short time, until the end of the therapy.

Table 3. TAS and TOS findings in blood samples and peritoneal fluid

\begin{tabular}{lll}
\hline Parameters & Blood & Peritoneal Fluid \\
\hline TAS (mmolTrolox eq./L) & 0.042 & 0.12 \\
TOS $(\mu \mathrm{mol} \mathrm{H2O2/L)}$ & 6.542 & 9.318 \\
\hline
\end{tabular}

L-carnitine metabolism is impaired in patients with hepatic impairment. Deficiency of L-carnitine might be a secondary factor for liver injuries $(19,20)$. It is reported that L-carnitine has protective effects on liver with its potent free radical scavenging and antioxidant actions against oxidative damage in hepatic ischemia-reperfusion injury (21). L-carnitine was administered during the time of treatment, and weekly liver enzyme analysis was performed. The liver enzyme concentrations were decreased during the time of treatment. L-carnitine might improve liver damage, and might prolong the survival time with liver protection effect.

\section{CONCLUSION}

In summary, thrombosis of vena cava caudalis, also known as BCS, was described for the first time in a domestic cat in Turkey. Ultrasound can be used as reliable non-invasive diagnostic method for detecting BCS. Furthermore, in the cat with BCS, the use of L-carnitine which has hepatoprotective effects was beneficial as supportive treatment. Medical treatment for BCS was not completely effective, only surgical removing of occlusion ensured normal bloodstream in vena cava caudalis. This study will be of great importance for future studies, diagnosis and "treatments" of BCS in animals.

\section{ACKNOWLEDGEMENT}

The authors would like to thank Prof. V. Soydal Ataseven, DVM, PhD. from Department of Virology, Faculty of Vet. Medicine, Mustafa Kemal Univ., Hatay, Turkey for his help with the PCR analysis.

\section{REFERENCES}

1. Simpson, I.W. (1982). Membranous obstruction of the inferior vena cava and hepatocellular carcinoma in South Africa. Gastroenterol. 82, 171-178.
2. Stanley, P. (1989). Budd-Chiari syndrome. Radiol. 170, 625-627.

http://dx.doi.org/10.1148/radiology.170.3.2644657 PMid:2644657

3. Nakamura T., Nakamura S., Aikawa T., Suziki, O., Onodera, A., Karoji, N. (1968). Obstruction of the inferior vena cava in the hepatic portion and the hepatic veins. Angiol. 19(8): 479-500. http://dx.doi.org/10.1177/000331976801900805

4. Amesur, N.B., Zajko, A.B. (2006). Interventional radiology in liver transplantation. Liver Transpl Surg. 12, 330-351.

http://dx.doi.org/10.1002/lt.20731

PMid:16498660

5. Zhang, X., Qing-Le, L. (2007). Etiology, treatment, and classification of Budd-Chiari syndrome. Chin Med J. 120, 159-161.

http://dx.doi.org/10.3901/JME.2007.04.159

6. Durgut, R., Ataseven, V.S., Sagkan-Ozturk, A., Ozturk, O.H. (2013). Evaluation of total oxidative stress and total antioxidant status in cows with natural bovine herpesvirus-1 infection. J Anim Sci. 91, 1-5. http://dx.doi.org/10.2527/jas.2012-5516 PMid:23798525

7. Erel, O. (2004). A novel automated method to measure total antioxidant response against potent free radical reactions. Clin Biochem. 37, 112-119.

http://dx.doi.org/10.1016/j.clinbiochem.2003.10.014 PMid:14725941

8. Erel, O. (2005). A new automated colorimetric method for measuring total oxidant status. Clin Biochem. 38, 1103-1111

http://dx.doi.org/10.1016/j.clinbiochem.2005.08.008 PMid:16214125

9. Schrope, D.S. (2010). Hepatic vein stenosis (BuddChiari syndrome) as a cause of ascites in a cat. J Vet Cardiol. 12, 197-202.

http://dx.doi.org/10.1016/j.jvc.2010.05.002

PMid:21078565

10. Okuda, K., Kage, M., Shrestha, S.M. (1998). Proposal of a new nomenclature for Budd-Chiari syndrome: hepatic vein thrombosis versus thrombosis of the inferior vena cava at its hepatic portion. Hepatology 28, 1191-1198.

http://dx.doi.org/10.1002/hep.510280505 PMid:9794901

11. Okuda, K. (2001). Membranous obstruction of the inferior vena cava (obliterative hepatocavopathy, Okuda). J Gastroenterol Hepatol. 16, 1179-1183. http://dx.doi.org/10.1046/j.1440-1746.2001.02577.x PMid:11903732 
The effects of L-carnitine in Budd-Chiari syndrome in a domestic cat

12. Takayasu, K., Muramatsu, Y., Moriyama, N., Wakao, F., Makuuchi, M., Takayama, T., Kosuge, T., Okazaki, N., Yamada, R. (1994). Radiological study of idiopathic Budd-Chiari syndrome complicated by hepatocellular carcinoma: a report of four cases. Am J Gastroenterol. 88, 249-253.

13. Horoz, M., Bolukbas, C., Bolukbas, F.F., Aslan, M., Koylu, A.O., Selek, S., Erel, O. (2006). Oxidative stres in hepatitis $\mathrm{C}$ infected end-stage renal disease subjects. BMC Infect Dis. 6, 114.

http://dx.doi.org/10.1186/1471-2334-6-114

PMid:16842626 PMCid:PMC1543638

14. Karaagac, L., Koruk, S.T., Koruk, I., Aksoy, N. (2011). Decreasing oxidative stress in response to treatment in patients with brucellosis: could it be used to monitor treatment. Int J Infect Dis. 15(5): 346-349. http://dx.doi.org/10.1016/j.ijid.2011.01.009 PMid:21376649

15. Karsen, H., Sunnetcioglu, M., Ceylan, R.M. (2011). Evaluation of oxidative status in patients with Fasciola hepatica infection. Afr Health Sci. 11(1): 14-18. http://dx.doi.org/10.4314/ahs.v11i3.70064

16. Maden, M., Ozturk, S.A., Bulbul, A., Avci, G., Yazar, E. (2012). Acute phase proteins, oxidative stress and enzyme activities of blood serum and peritoneal fluid in abomasal displacement cases. J Vet Intern Med. 26, 1470-1475.

http://dx.doi.org/10.1111/j.1939-1676.2012.01018.x PMid:23113812

17. Braun, U. (2008). Clinical findings and diagnosis of thrombosis of the caudal vena cava in cattle. The Vet J. $175,118-125$.

http://dx.doi.org/10.1016/j.tvj1.2006.11.013

PMid:17239635
18. Fisher, N.C., Mccafferty, I., Dolapci, M., Wali, M., Buckels, J.A.C., Olliff, S.P., Elias, E. (1999). Managing Budd-Chiari syndrome: a restrospective review of percutaneous hepatic vein angioplasty and surgical shunting. Gut 44, 568-574.

http://dx.doi.org/10.1136/gut.44.4.568

PMid:10075967 PMCid:PMC1727471

19. Lin, X.H., Jiao, L.L., Xu, G.B., Tian, G.S. (2006). Significance of serum carnitine in patients with liver diseases. Zhonghua Gan Zang Bing ZaZhi, 14(5): 367-369.

20. Malaguarnera,M.,Vacante,M.,Giordano,M.,Motta,M., Bertino, G., Pennisi, M., Neri, S., Malaguernera, M., Li Volti, G., Galvano, F. (2011). L-carnitine supplementation improves hematological pattern in patients affected by HCV treated with Peg interferon- $\alpha$ $2 \mathrm{~b}$ plus ribavirin. World J Gastroenterol. 17(39): 4414-4420.

http://dx.doi.org/10.3748/wjg.v17.i39.4414

PMid:22110268 PMCid:PMC3218156

21. Cekin,AH., Gur, G., Turkoglu, S., Aldemir, D., Yılmaz, U., Gursoy, M., Taskoparan, M., Boyacioğlu, S. (2013). The protective effect of L-carnitine on hepatic ischemia-reperfusion injury in rats. Turk $\mathrm{J}$ Gastroenterol. 24 (1): 51-56.

PMid:23794344 